NASZA DERMATOLOGIA Online OUR DERMATOLOGY Online Nil

Competing Interests: None

\section{HEMATOMA OF THE PROXIMAL NAIL FOLD DUE TO OXIMETER IN A CHILD}

\author{
Patricia Chang ${ }^{1}$, Monica Vanesa Vásquez Acajabón ${ }^{2}$ \\ ${ }^{1}$ Department of Dermatology, Hospital General de Enfermedades IGSS and Hospital \\ Ángeles, Guatemala \\ ${ }^{2}$ Hospital General de Enfermedades IGSS and Hospital Ángeles, Guatemala
}

Corresponding author: Patricia Chang, $\mathrm{MD} \mathrm{PhD}$

pchang2622@gmail.com
Boy 4 years old, hospitalized due to hemorrhagic chickenpox and sepsis during his clinical examination besides hemorrhagic crust, vesicles and bullous he has also a cutaneous red lesion localized at the right proximal nail fold of the big toenail (Fig. 1), dermatoscopic view of the lesion (Fig. 2).

The diagnosis of hematoma of the proximal nail fold due to oximeter was done.

The proximal nail fold hematomas due to oximeter are uncommon dermatoses at this level that are caused for the pressure of the oximeter and it has been seeing in patient in Unit Intensive or Intermediate Unit Care since 2007.

Hematomas are blood collections located at any part of the body. The hematoma of the nail or periungual tissues can be caused by trauma or systemic diseases [1,2]. Usually the proximal nail folds of fingers, are exposed to receive minor and mayor traumas, and it is important to distinguish clinically from other diseases [1,3].

These kinds of hematomas go unnoticed, and are resulted by constant friction caused by the use of oximeter. The proximal

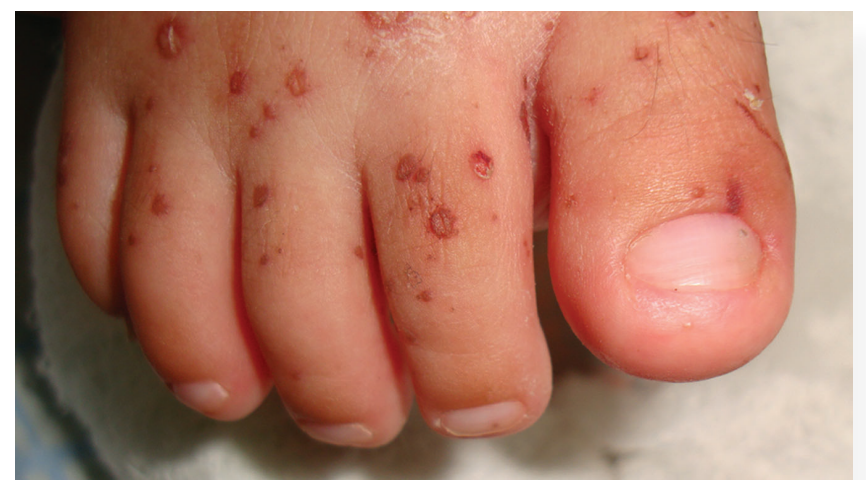

Figure 1. Hematoma of the proximal nail fold on the right big toenail. nail fold hematoma affects the free edge letting off the cuticle; its appearance has been seen after 1 to 3 days of using the oximeter. One or more folds can be affected according to where the oximeter is placed proximal nail $[1,4]$.

However, it is important to know other hematomas at this level, as those are produced by the oximeter use; their presence in several digits and no history of oximeter use; make us suspect other diseases that can be presented such as repeated collagen diseases or sepsis [5].

Chang and Haneke reported the first 3 cases of proximal nail fold hematoma on 2008 , later reported 41 cases of the proximal nail fold hematoma in adult patients from the intermediate and intensive care unit at the Hospital General de Enfermedades on 2011 [4]. Also this pathology has been described in children, 5 cases were reported in children between the ages of 5 months to 4 years old on 2013 [6].

There is no treatment for this affection; prevention of injury is to rotate the oximeter every two or three hours to prevent the formation of hematoma [6].

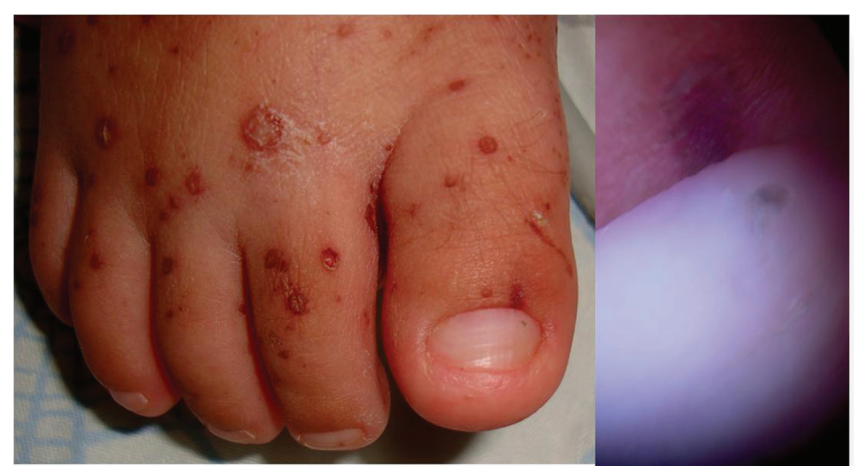

Figure 2. Dermatoscopic view of proximal nail fold due to oximeter. 


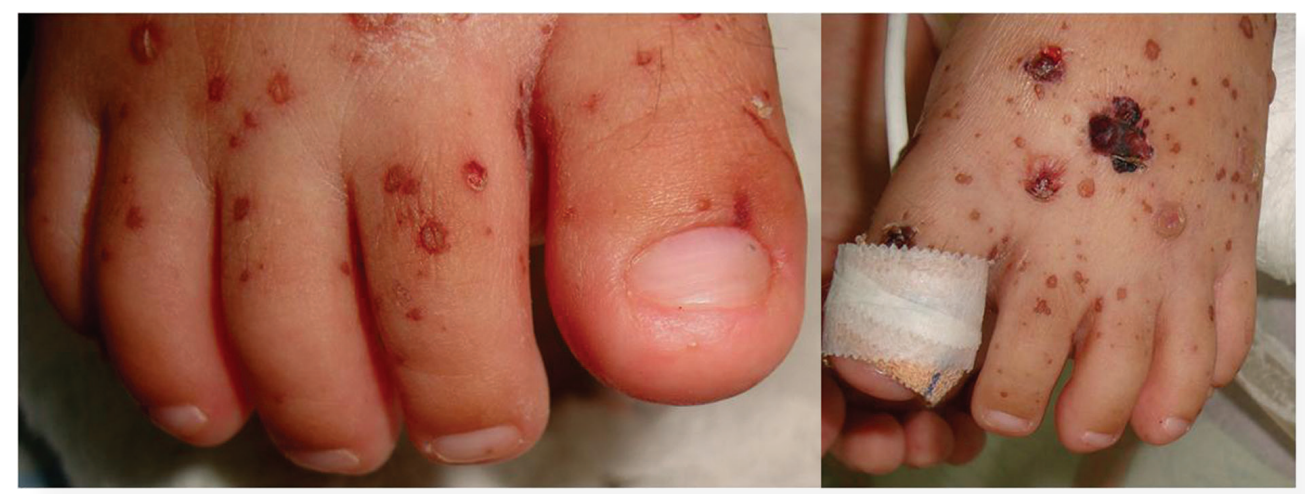

Figure 3. View of the oximeter in children.

\section{REFERENCES}

1. Chang P, Haneke E, Rodas A. Hematoma del aparato ungueal. DCMQ, 2009;7:196-201.

2. Bassoti A. Patologia Ungueal, Facultad de ciencias medicas, Universidad de Cuyo, Argentina. http://www.fcm.uncu.edu.ar/ medicina/posgrado/dermatologia/teoricos/UniaII.pdf, consulted on Agust 18th of 2013
3. Braun RP, Baran R, Le Gal FA, Dalle S, Ronger S, Pandolfi R, et al. Diagnosis and management of nail pigmentations. J Am Acad Dermatol. 2007;56:835-47.

4. Chang P, Rodas C. Hematoma of the proximal nail. Report of 41 cases. Our Dermatol Online. 2011;2:65-7.

5. Chang P, Haneke E. Dermatosis del pliegue proximal ungueal. DCMQ. 2011;9:96-101.

6. Chang P. Hematoma de pliegue proximal ungueal en niños: informe de 5 casos. DCMQ. 2013;11:156-7.

Copyright by Patricia Chang, et al. This is an open access article distributed under the terms of the Creative Commons Attribution License, which permits unrestricted use, distribution, and reproduction in any medium, provided the original author and source are credited. 